\title{
PHYSICOCHEMICAL AND SENSORY PROPERTIES OF ICE CREAM PRODUCED USING RAW AND PROCESSED MILK
}

\author{
Kalaiarasi Gnanaprakasam \\ Assistant Professor, Department of Food Technology \\ Dhanalakshmi Srinivasan College of Engineering, Coimbatore, Tamil Nadu, India
}

\begin{abstract}
The present study was carried out to examine the effect of storage period on the physicochemical, sensory quality of Ice cream produced using Raw (Cow and Buffalo milk) and processed milk (Full cream and Standardized milk). Based on the different ratio of milk (Raw 25\% cow milk and $\mathbf{7 5 \%}$ buffalo milk, 50\% cow milk and 50\% buffalo milk, $100 \%$ cow milk, $100 \%$ buffalo milk, $25 \%$ buffalo milk and $75 \%$ cow milk) and (Processed 25\% full cream milk and 75\% Standard milk, $50 \%$ full cream milk and $50 \%$ standard milk, $100 \%$ full cream milk, $100 \%$ standardized milk, $\mathbf{2 5 \%}$ standard milk and $\mathbf{7 5 \%}$ full cream milk), the Ice cream is evaluated periodically at intervals of 15 days. According to results obtained, the properties like total solids and acidity of ice cream samples were increased significantly. While, pH and overrun decreased significantly. There are no significant changes occurred in Fat and Protein during storage. The mean sensory score of all Ice cream samples decreased significantly with progress in storage period at $-18 \pm 1^{\circ} \mathrm{C}$.
\end{abstract}

Keywords - Ice cream, Raw milk, Processed Milk, Physicochemical, Sensory.

\section{INTRODUCTION}

Ice cream is a frozen product that is made by pasteurization and mix freezing, which includes milk components, sucrose, dextrose, corn syrup, water, egg and egg products, flavoring components, stabilizer, emulsifier and optionally other components (Kurdar, 2003). Ice cream was eaten in only different seasons by adding some sugar, sherbet, fruit or wine to the ice cream. Today, however, it is an industrial product that contains different food additives and can be consumed in all seasons (Açu, 2014). Due to a number of biochemical variations between Buffalo and Cow milk, traditional processing techniques are often unsuitable and cannot be applied directly to buffalo milk processing. The suitability of buffalo as a milk producer is now becoming more and more important throughout the world. The lack of research and knowledge on this has been a major bottleneck in maximizing the production capacity of buffaloes. (Khedkar et al., 2016).

Milk is said to be dietry food for human. It is the first food of a newly born human being and of other mammals. It is a food that contains all the nutrients required for a newborn baby, pregnant mothers, patients and elderly people. There is no question that milk and milk products have played a key role in the development of human society and provide most of the essential nutrients in significant quantities than any other single food. It is very important for the growth and development of a newborn child. Milk contains all essential nutrients such as protein, fat, lactose, vitamins and minerals for normal growth and performs different functions for body systems.

Potassium helps maintain blood pressure. Vitamin B12 promotes healthy red blood cells and nerve tissues. Vitamin A is good for the skin and increases immunity.

Full cream milk is recommended for children, adolescents, body builders, pregnant and lactating mothers. Standardized milk is a commodity whose fat and/or non-fat (SNF) content has been standardized to a certain pre-determined amount. Under the PFA Regulations (1976), standardized milk for liquid consumption should contain at least 4.5 per cent of fat and 8.5 per cent of SNF throughout the region.

The study aims to produce ice cream with different ratios of Raw (Cow milk and buffalo milk) and Processed (Full cream and standardized milk) with different ratios as a local flavored and nutritionally supported product and to study the physio-chemical and organoleptic properties of the product.

\section{A. Material}

\section{MATERIAL AND METHOD}

Raw cow and Buffalo milk are purchased from the nearer village, Chidambaram. Processed milk (Full cream milk and standardized milk) are purchased from the local market. The other ingredients like sugar, butter, skimmed milk powder (SMP), Butter, Stabilizer and Emulsifier are purchased from the local market, Chidambaram.

\section{B. Method}


Ice cream production was carried in Annamalai University, Food Processing Technology Laboratory. Raw Cow and Buffalo milk are taken in five different ratios and, processed Full cream and standardized cream are taken in five different ratios. The composition of Raw milk is shown in Table 1 and Processed milk is shown in Table 2.

Table 1. Composition of Raw milk

\begin{tabular}{|c|c|}
\hline Sample & Composition \\
\hline A & $100 \%$ Cow milk \\
\hline B & $75 \%$ Cow milk and 25\% Buffalo milk \\
\hline C & $50 \%$ Cow milk and 50\% Buffalo milk \\
\hline D & $75 \%$ Buffalo milk and 25\% Cow milk \\
\hline E & $100 \%$ Buffalo milk \\
\hline
\end{tabular}

Table 2. Composition of Processed milk

\begin{tabular}{|c|c|}
\hline Sample & Composition \\
\hline A & $100 \%$ Full cream milk \\
\hline B & $\begin{array}{c}75 \% \text { Full cream milk and 25\% } \\
\text { Standardized milk }\end{array}$ \\
\hline C & $\begin{array}{c}50 \% \text { Full cream milk and 50\% } \\
\text { Standardized milk }\end{array}$ \\
\hline D & $\begin{array}{c}75 \% \text { Standardized milk and 25\% Full } \\
\text { cream milk }\end{array}$ \\
\hline E & $100 \%$ Standardized milk \\
\hline
\end{tabular}

Weighed dry ice cream ingredients were were added to milk samples and they were heat treated at $90^{\circ} \mathrm{C}$ for 10 minutes. Heat treated mixes were cooled to $4^{\circ} \mathrm{C}$ and stored at this temperature for 24 hours. Ice cream mixtures were frozen by Batch type ice cream machine at $-15^{\circ} \mathrm{C}$ for 15 minutes. After packaging they were stored at $-18 \pm 1{ }^{\circ} \mathrm{C}$.

Physico-chemical analysis: Moisture, ash, protein and titratable acidity were determined according to AOAC (2000) method. $\mathrm{pH}$ of samples was measured using digital $\mathrm{pH}$ meter. Overrun of Ice cream was calculated on weight basis using the following formula.

Overrun $\%$

$=$ wt. of ice cream mix - wt. of ice cream $* 100$

Wt. of ice cream mix

Sensory quality: Ice cream samples were evaluated by a semi trained panel of 8 judges for the attributes of texture, flavour, taste and overall acceptability scores on a 9-point hedonic scale (Larmond 1970).

\section{RESULT}

Some physicochemical properties of ice cream samples that were produced by Raw cow milk and Buffalo milk were showed at Table 3. Ice cream obtained by $100 \%$ Cow milk was defined as A sample, 75\% Cow milk and 25\% Buffalo milk was defined as B sample, 50\% Cow milk and 50\% Buffalo milk was defined as C sample, $75 \%$ Buffalo milk and $25 \%$ Cow milk was defined as D sample and 100\% Buffalo milk was defined as E sample.

Table 3. Effect of Storage on Physicochemical properties of Raw milk Ice cream

\begin{tabular}{|c|c|c|c|c|c|}
\hline \multirow{2}{*}{$\begin{array}{l}\text { Ice } \\
\text { cream } \\
\text { type }\end{array}$} & \multicolumn{5}{|c|}{ Storage period } \\
\hline & 0 & 15 & 30 & 45 & 60 \\
\hline \multicolumn{6}{|l|}{$\mathrm{pH}$} \\
\hline $\mathrm{A}$ & 6.56 & 6.54 & 6.51 & 6.49 & 6.47 \\
\hline B & 6.66 & 6.65 & 6.63 & 6.61 & 6.60 \\
\hline $\mathrm{C}$ & 6.76 & 6.75 & 6.73 & 6.72 & 6.71 \\
\hline D & 6.78 & 6.77 & 6.75 & 6.74 & 6.73 \\
\hline $\mathrm{E}$ & 6.78 & 6.77 & 6.75 & 6.73 & 6.72 \\
\hline \multicolumn{6}{|c|}{ Overrun } \\
\hline $\mathrm{A}$ & 42 & 41.73 & 41.59 & 41.31 & 40.70 \\
\hline $\mathrm{B}$ & 45.6 & 45.12 & 44.8 & 44.62 & 44.38 \\
\hline $\mathrm{C}$ & 54.9 & 54.63 & 54.15 & 53.46 & 53.13 \\
\hline $\mathrm{D}$ & 60.10 & 59.72 & 59.63 & 59.42 & 59.38 \\
\hline $\mathrm{E}$ & 61.3 & 61.19 & 60.85 & 60.32 & 59.90 \\
\hline \multicolumn{6}{|c|}{ Total Solids } \\
\hline A & 27.9 & 28.17 & 28.52 & 29.20 & 29.42 \\
\hline $\mathrm{B}$ & 29.18 & 29.72 & 30.23 & 30.95 & 31.13 \\
\hline $\mathrm{C}$ & 30.61 & 31.05 & 31.62 & 32.10 & 32.59 \\
\hline $\mathrm{D}$ & 32.19 & 32.46 & 32.90 & 33.43 & 34.1 \\
\hline $\mathrm{E}$ & 37.72 & 37.96 & 38.18 & 38.53 & 38.97 \\
\hline \multicolumn{6}{|c|}{ Titratable acidity } \\
\hline A & 0.19 & 0.193 & 0.103 & 0.195 & 0.2 \\
\hline B & 0.198 & 0.2 & 0.212 & 0.215 & 0.215 \\
\hline $\mathrm{C}$ & 0.193 & 0.194 & 0.194 & 0.195 & 0.196 \\
\hline $\mathrm{D}$ & 0.195 & 0.206 & 0.212 & 0.218 & 0.22 \\
\hline $\mathrm{E}$ & 0.199 & 0.21 & 0.214 & 0.221 & 0.231 \\
\hline \multicolumn{6}{|c|}{ Protein } \\
\hline $\mathrm{A}$ & 4.31 & 4.31 & 4.32 & 4.33 & 4.33 \\
\hline B & 4.62 & 4.62 & 4.62 & 4.62 & 4.62 \\
\hline $\mathrm{C}$ & 4.82 & 4.82 & 4.82 & 4.83 & 4.83 \\
\hline $\mathrm{D}$ & 4.84 & 4.84 & 4.84 & 4.84 & 4.84 \\
\hline $\mathrm{E}$ & 5.12 & 5.12 & 5.12 & 5.12 & 5.12 \\
\hline \multicolumn{6}{|l|}{ Fat } \\
\hline $\mathrm{A}$ & 4.7 & 4.7 & 4.7 & 4.7 & 4.7 \\
\hline $\mathrm{B}$ & 4.92 & 4.92 & 4.93 & 4.93 & 4.93 \\
\hline $\mathrm{C}$ & 5.98 & 5.99 & 5.99 & 5.99 & 5.99 \\
\hline $\mathrm{D}$ & 6.52 & 6.52 & 6.52 & 6.52 & 6.52 \\
\hline$E$ & 6.9 & 6.9 & 6.9 & 6.9 & 6.9 \\
\hline
\end{tabular}


International Journal of Engineering Applied Sciences and Technology, 2021

Vol. 6, Issue 1, ISSN No. 2455-2143, Pages 218-222

Published Online May 2021 in IJEAST (http://www.ijeast.com)

\begin{tabular}{|l|l|l|l|l|l|}
\hline Ash \\
\hline A & 0.75 & 0.75 & 0.74 & 0.73 & 0.73 \\
\hline B & 0.75 & 0.74 & 0.74 & 0.74 & 0.73 \\
\hline C & 0.79 & 0.79 & 0.78 & 0.77 & 0.76 \\
\hline D & 0.89 & 0.89 & 0.88 & 0.87 & 0.87 \\
\hline E & 0.83 & 0.82 & 0.82 & 0.81 & 0.81 \\
\hline
\end{tabular}

Some physicochemical properties of ice cream samples that were produced by Full cream milk and Standardized milk were showed at Table 4 . Ice cream obtained by $100 \%$ Full cream milk was defined as A sample, $75 \%$ Full cream milk and $25 \%$ Standardized milk was defined as B sample, 50\% Full cream milk and 50\% Standardized milk was defined as C sample, $75 \%$ Standardized milk and $25 \%$ Full cream milk was defined as D sample and 100\% Standardized milk was defined as E sample.

Table 4. Effect of Storage on Physicochemical properties of Processed milk Ice cream

\begin{tabular}{|c|c|c|c|c|c|}
\hline \multirow{2}{*}{$\begin{array}{l}\text { Ice } \\
\text { cream } \\
\text { type }\end{array}$} & \multicolumn{5}{|c|}{ Storage Period } \\
\hline & 0 & 15 & 30 & 45 & 60 \\
\hline \multicolumn{6}{|l|}{$\mathrm{pH}$} \\
\hline A & 6.44 & 6.12 & 5.93 & 5.62 & 5.21 \\
\hline B & 6.34 & 6.11 & 5.90 & 5.72 & 5.32 \\
\hline $\mathrm{C}$ & 6.44 & 6.29 & 5.98 & 5.42 & 5.04 \\
\hline D & 6.54 & 6.09 & 5.84 & 5.28 & 4.85 \\
\hline $\mathrm{E}$ & 6.54 & 6.11 & 5.83 & 5.42 & 5.15 \\
\hline \multicolumn{6}{|c|}{ Overrun } \\
\hline $\mathrm{A}$ & 41 & 40.62 & 40.17 & 39.64 & 39.21 \\
\hline $\mathrm{B}$ & 44.3 & 43.82 & 43.21 & 42.68 & 42.18 \\
\hline $\mathrm{C}$ & 48.6 & 48.11 & 47.58 & 47.10 & 46.52 \\
\hline $\mathrm{D}$ & 51.05 & 50.63 & 50.21 & 49.93 & 49.32 \\
\hline $\mathrm{E}$ & 53.8 & 53.21 & 52.84 & 52.15 & 51.84 \\
\hline \multicolumn{6}{|c|}{ Total Solids } \\
\hline A & 23.18 & 23.52 & 23.96 & 24.52 & 25.12 \\
\hline $\mathrm{B}$ & 23.9 & 24.52 & 25.08 & 25.95 & 26.54 \\
\hline $\mathrm{C}$ & 24.6 & 25.35 & 24.85 & 24.02 & 23.85 \\
\hline $\mathrm{D}$ & 25.12 & 24.54 & 23.66 & 23.98 & 23.57 \\
\hline $\mathrm{E}$ & 26.01 & 25.64 & 24.87 & 24.03 & 23.72 \\
\hline \multicolumn{6}{|c|}{ Titratable acidity } \\
\hline $\mathrm{A}$ & 0.216 & 0.219 & 0.228 & 0.234 & 0.238 \\
\hline $\mathrm{B}$ & 0.221 & 0.237 & 0.239 & 0.231 & 0.235 \\
\hline $\mathrm{C}$ & 0.226 & 0.235 & 0.239 & 0.241 & 0.242 \\
\hline $\mathrm{D}$ & 0.23 & 0.234 & 0.235 & 0.237 & 0.237 \\
\hline $\mathrm{E}$ & 0.232 & 0.236 & 0.238 & 0.239 & 0.24 \\
\hline \multicolumn{6}{|l|}{ Protein } \\
\hline $\mathrm{A}$ & 4.3 & 4.3 & 4.31 & 4.31 & 4.31 \\
\hline B & 4.28 & 4.28 & 4.28 & 4.28 & 4.29 \\
\hline
\end{tabular}

\begin{tabular}{|l|l|l|l|l|l|}
\hline C & 4.31 & 4.31 & 4.32 & 4.32 & 4.32 \\
\hline D & 4.31 & 4.31 & 4.31 & 4.32 & 4.32 \\
\hline E & 4.29 & 4.29 & 4.30 & 4.30 & 4.30 \\
\hline Fat \\
\hline A & 6.52 & 6.52 & 6.53 & 6.53 & 6.53 \\
\hline B & 5.98 & 5.98 & 5.98 & 5.99 & 5.99 \\
\hline C & 5.51 & 5.51 & 5.52 & 5.52 & 5.53 \\
\hline D & 4.83 & 4.83 & 4.84 & 4.84 & 4.84 \\
\hline E & 4.31 & 4.31 & 4.32 & 4.32 & 4.32 \\
\hline Ash \\
\hline A & 0.7 & 0.71 & 0.72 & 0.73 & 0.73 \\
\hline B & 0.69 & 0.70 & 0.70 & 0.71 & 0.73 \\
\hline C & 0.69 & 0.69 & 0.70 & 0.70 & 0.70 \\
\hline D & 0.68 & 0.69 & 0.70 & 0.70 & 0.71 \\
\hline E & 0.69 & 0.70 & 0.71 & 0.71 & 0.72 \\
\hline
\end{tabular}

Effect of storage on Physicochemical properties of Raw and Processed milk Ice cream:

Total solids play an important role in the quality of ice cream. Total solid content of all ice cream samples increased significantly during storage period (Table 3 and 4). The elevation in total solids of all ice cream samples may be attributed to the loss of moisture from the samples during storage. Abdullah et al. (2003) stated that there was an increase in total solid content which he analyzed soymilk and skim milk Ice cream. No significant changes occurs in the fat, protein and ash during the storage of the Raw and Processed milk Ice cream.

The acidity of all ice cream samples increased significantly during the storage period while $\mathrm{pH}$ value decreased progressively (Table 3 and 4). Due to the the formation of lactic acid by lactic acid bacteria (LAB) and psychrophillic bacteria during storage, the acidity of a product is increased (Murtaza et al. 2004a). The results of this study are similar to those reported by Siddique et al. (1988), Abdullah et al. (2003) and Murtaza et al. (2004a) who found that there was a gradual increase in acidity on storage of ice cream. The $\mathrm{pH}$ has a direct effect on the flavour perception of the dairy products (Hegenbert 1991) and a decrease in $\mathrm{pH}$ was observed all over the storage period. This was due to increase in titratable acidity of ice cream. The overrun of the Raw and Processed milk Ice cream is seen to be decreased during the storage.

\section{Effect of Storage on Sensory:}

The sensory score of the Raw and Processed milk Ice cream was observed for storage period of 15 day interval. There is no big difference observed in the Texture, Flavour, Taste and Overall acceptability. Slightly, there is a difference occurs during the storage. The result of sensory score is shown in the Table 5 and 6. 
International Journal of Engineering Applied Sciences and Technology, 2021

Vol. 6, Issue 1, ISSN No. 2455-2143, Pages 218-222

Published Online May 2021 in IJEAST (http://www.ijeast.com)

Table 5. Effect of storage on Sensory analysis of Raw milk Ice cream

\begin{tabular}{|c|c|c|c|c|c|}
\hline \multirow{5}{*}{$\begin{array}{c}\text { Ice } \\
\text { cream } \\
\text { type }\end{array}$} & 0 & 15 & 30 & 45 & 60 \\
\cline { 2 - 6 } Texture & \multicolumn{5}{|c|}{ Storage period } \\
\hline A & 7.9 & 7.8 & 7.8 & 7.9 & 7.9 \\
\hline B & 7.5 & 7.6 & 7.6 & 7.75 & 7.75 \\
\hline C & 7.5 & 7.55 & 7.5 & 7.6 & 7.6 \\
\hline D & 7.6 & 7.6 & 7.65 & 7.65 & 7.65 \\
\hline E & 8.2 & 8.2 & 8.25 & 8.3 & 8.35 \\
\hline Flavor & \multicolumn{5}{|c|}{} \\
\hline A & 7.70 & 7.54 & 7.39 & 7.22 & 7.05 \\
\hline B & 8.25 & 8.18 & 8.10 & 7.93 & 7.81 \\
\hline C & 8.13 & 8.03 & 7.93 & 7.72 & 7.53 \\
\hline D & 8.16 & 8.08 & 8.0 & 7.92 & 7.63 \\
\hline E & 8.3 & 8.32 & 8.3 & 8.21 & 8.3 \\
\hline Taste & 7.7 & 7.65 & 7.6 & 7.65 & 7.65 \\
\hline A & 7.7 & 7.8 & 7.8 & 7.75 & 7.75 \\
\hline B & 7.9 & 7.8 & 7.52 & 7.55 \\
\hline C & 7.6 & 7.63 & 7.6 & 7.52 \\
\hline D & 7.53 & 7.25 & 7.05 & 7.05 & 7.1 \\
\hline E & 8.0 & 7.95 & 7.95 & 7.9 & 7.9 \\
\hline Overall acceptability \\
\hline A & 8.1 & 8.05 & 8.1 & 8.1 & 8.0 \\
\hline B & 8.15 & 8.15 & 8.10 & 8.10 & 8.10 \\
\hline C & 8.1 & 8.1 & 8.12 & 8.0 & 8.0 \\
\hline D & 8.2 & 8.15 & 8.1 & 8.1 & 8.1 \\
\hline E & 8.2 & 8.15 & 8.15 & 8.15 & 8.1 \\
\hline \multicolumn{7}{|c|}{} \\
\hline
\end{tabular}

Table 6. Effect of storage on Sensory analysis of Processed milk Ice cream

\begin{tabular}{|l|l|l|l|l|l|}
\hline $\begin{array}{l}\text { Ice } \\
\text { cream } \\
\text { type }\end{array}$ & \multicolumn{5}{|l|}{ Storage period } \\
\cline { 2 - 6 } & 0 & 15 & 30 & 45 & 60 \\
\hline Texture & \multicolumn{5}{|l|}{} \\
\hline A & 7.6 & 7.65 & 7.65 & 7.6 & 7.6 \\
\hline B & 7.65 & 7.7 & 7.7 & 7.65 & 7.6 \\
\hline C & 7.7 & 7.7 & 7.65 & 7.65 & 7.62 \\
\hline D & 7.3 & 7.3 & 7.25 & 7.2 & 7.2 \\
\hline E & 7.7 & 7.6 & 7.54 & 7.5 & 7.5 \\
\hline Flavour \\
\hline A & 8.0 & 7.98 & 7.7 & 7.64 & 7.64 \\
\hline B & 7.9 & 7.83 & 7.79 & 7.71 & 7.63 \\
\hline C & 7.9 & 7.86 & 7.82 & 7.72 & 7.7 \\
\hline D & 7.95 & 7.92 & 7.92 & 7.90 & 7.90 \\
\hline E & 7.92 & 7.89 & 7.83 & 7.85 & 7.8 \\
\hline Taste & 7.75 & 7.73 & 7.73 & 7.74 & 7.8 \\
\hline A
\end{tabular}

\begin{tabular}{|l|l|l|l|l|l|}
\hline B & 7.8 & 7.83 & 7.88 & 7.88 & 7.86 \\
\hline C & 7.83 & 7.80 & 7.74 & 7.62 & 7.58 \\
\hline D & 7.78 & 7.53 & 7.28 & 7.19 & 7.2 \\
\hline E & 8.0 & 8.1 & 8.05 & 8.15 & 8.15 \\
\hline \multicolumn{5}{|l|}{ Overall acceptability } \\
\hline A & 8.1 & 8.09 & 7.93 & 7.84 & 7.78 \\
\hline B & 8.23 & 8.17 & 8.06 & 7.93 & 7.85 \\
\hline C & 8.35 & 8.23 & 8.14 & 7.98 & 7.57 \\
\hline D & 8.38 & 8.18 & 7.97 & 7.58 & 7.5 \\
\hline E & 8.0 & 7.93 & 7.76 & 7.67 & 7.54 \\
\hline
\end{tabular}

\section{IV.CONCLUSION}

Results of this analysis showed that as the storage period progressed, the total solid content of all samples increased due to loss of moisture during ice cream storage although no changes in protein, fat and ash content were observed during this time. Increased acidity of all ice cream samples due to lactic acid growth and decreased $\mathrm{pH}$ with improved storage. Reduced overrun resulting in decreased storage capacity. Sensory scores of all ice cream samples have been found to decrease slowly with storage.

\section{REFERENCE}

[1] Abdullah M, Rehman S, Zubair H, Saeed H M, Kousar S and Shahid M. (2003). Effect of skim milk in soymilk blend on the quality of ice cream. Pakistan J Nutr 2, (pp. 305-311).

[2] AOAC Official Methods of Analysis. (2000). 17th Edition. Association of Official Analytical Chemists, Gathersberg, Maryland, USA.

[3] Arashdeep singh, Usha Bajwa, Rajpreet Kaur Goraya. (2014). Effect of Storage period on the Physicochemical, Sensory and Microbiological quality of Bakery Flavoured Ice cream. International journal of Engineering Research and Applications, ISSN: 2248 - 9622, Vol. 4, Issue 8, (pp. 80 - 90).

[4] Chandraprakash D. Khedkar, Shrikant D. Kalyankar, Shital Deosarkar. (2016). Buffalo milk. The Encyclopedia of Food and Health, Volume 1, (pp. 522 - 528).

[5] De S. (1997). Outlines of Dairy Technology. Oxford University Press, New Delhi, (pp. $182-183$ ).

[6] Earl FA and Tracy PH. (1960). The importance of temperature in the storage of ice cream. Ice cream Trade J. 56. (pp. $36-42$ ).

[7] Larmond E. (1970). Methods of sensory evaluation of food. Can Deptt. Agric Pubs 12847.

[8] Mahran GA, Alomy EHA, Bagoury EEH and Sayed AF (1987). Effect of storage temperature of milk fat on ice cream quality. Egyptian J Food Science 15, (pp. $65-73$ ). 
[9] Marshall RT and Arbuckle WS (1966). Ice cream. $5^{\text {th }}$ Chapman and Hall, International Thompson Publication, New York, (pp. 263 - 268).

[10] Murtaza MA, Din MU, Huma GN, Shabbir MA and Mahmoods. (2004). Quality evaluation of ice cream prepared with different stabilizers/emulsifier blends. Intl J Agric Biol 6, (pp.65-67)

[11] Potter NN and Hotchkiss JH. (1995). Food Science. $5^{\text {th }}$ Edition, CBS Publishers, New Delhi, India, (pp. 292 - 300).

[12] Siddiique MI, Mukhtar M, Rwhman S and A wan JA. (1988). Use of guar gum as a stabilizer in ice cream. Sci Technol Dev 7, (pp:10 - 14). 